See discussions, stats, and author profiles for this publication at: https://www.researchgate.net/publication/306098570

\title{
Una aproximación teórica a la dominación simbólica a partir del Corpus Christi colonial cuzqueño (Siglo XVII)
}

Article · January 2016

\section{CITATIONS}

0

2 authors:

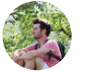

Francisco Franco

National University of Cordoba, Argentina

9 PUBLICATIONS OCITATIONS

SEE PROFILE

Some of the authors of this publication are also working on these related projects:

Equipo de Arqueología del Sur de las Cumbres Calchaquíes View project
READS

391

Agustina Fiorani

National University of Cordoba, Argentina

2 PUBLICATIONS OCITATIONS

SEE PROFILE 


\title{
Una aproximación teórica a la dominación simbólica a partir del Corpus Christi colonial cuzqueño (Siglo XVII)
}

\section{A theoretical approach to symbolic domination through the colonial cuzqueño Corpus Christi (17th century)}

\author{
Agustina Fiorani \\ agusfiorani@hotmail.com \\ Universidad Nacional de Córdoba
}

\section{Francisco Franco}

franfranco@unc.edu.ar

Universidad Nacional de Córdoba

Resumen. El presente artículo pretende llevar a cabo una reconstrucción teórica de la dominación simbólica de la Corona española en los Andes Centrales. Consideraremos para ello cómo se presenta la imposición discursiva/simbólica española en la fiesta de Corpus Christi en Cuzco, entendiendo que en la misma se entrelaza una mixtura de elementos hispánicos y andinos de larga data, construidos, reconstruidos y reproducidos a través de la agencia de cada grupo participante en el festejo.

Palabras Claves: historia colonial, corpus christi, dominación simbólica, hibridación cultural

\begin{abstract}
This article seeks to build a theoretical reconstruction of 'symbolic domination' during the Hispanic Conquest of the Andes. It uses as framework the discursive and symbolic imposition of the Corpus Christi festivity in Cuzco. This festivity mixes Iberian and Andean lengthy elements, built, rebuilt and reproduced through agencies of each group participating in the festivity.
\end{abstract}

Keywords: colonial history, corpus christi, symbolic domination, cultural hybridity

Fecha de recepción: 20 de marzo del 2016

Fecha de aprobación: 8 de mayo del 2016 


\section{Introducción}

Durante el último cuarto del siglo XVI, las reformas emprendidas por el Virrey Toledo consolidaron el dominio colonial español en el Virreinato del Perú al otorgarle al mismo una armazón institucional de larga duración que se mantuvo estable hasta el siglo XVIII. Con estas medidas se definieron los elementos centrales para la organización de un sistema colonial, justificado legal y éticamente por la necesidad de la evangelización, y organizado con el objetivo de garantizar el funcionamiento de un sistema económico extractivo donde la economía campesina indígena subsidió la economía del sistema colonial en su conjuntoํ. Para las poblaciones indígenas de los Andes, luego del "trauma inicial" de la Conquista se sucedió la progresiva desestructuración de los marcos políticos, demográficos, sociales y económicos que hasta entonces regían la vida en el Tawantinsuyu; un desmantelamiento de las organizaciones incaicas de largo aliento que no culminaría hasta muchos años después y que sería atravesado por las contradicciones inherentes al mismo dominio colonial.

La imposición material de la Corona española fue sustentada no solo a través de las armas y la violencia física, sino también con la implementación de un discurso particular, pretendidamente hegemónico, que buscaba silenciar las expresiones culturales precolombinas. En consecuencia, la dimensión simbólica de la subyugación implicó la desarticulación y negación de las cosmovisiones andinas, imposibles de trasladar en muchos casos a los modelos epistemológicos de tradición judeo-cristiana. En la acción y en la teoría, el Imperio Español legitimó su pretensión colonial a través de la imposición de modelos exógenos (compuesto por creencias y símbolos de raíz europea, occidental y católica) que redundaron en prácticas concretas de asimilación de los nativos al orden establecido.

$1 \quad$ Silvia Palomeque, "El sistema de dominación colonial en Andes de páramo" (inédito). Material de Lectura de la Cátedra Historia de América 1 (Córdoba: UNC, 1996): 1-18.

Artificios. Revista colombiana de estudiantes de historia. No. 5. Agosto de 2016. ISSN. 2422-118X 
Como lo entiende Frank Salomon ${ }^{2}$ un acercamiento riguroso a las fuentes documentales de la época permite encontrar las voces acalladas, la existencia de protagonistas subalternos al dominio español que se deslizan entre y sobre las contradicciones del poder y del discurso colonial. El uso del término discurso, específicamente del discurso colonial en, destaca la mutua internalización de relaciones entre grupos europeos e indígenas en un orden sociocultural mayor ${ }^{3}$.

Los españoles intentaron construir un discurso cultural monolítico que, en la práctica resultó extremadamente poroso y elástico. Al interior del dominio discursivo español se pueden observar las fisuras del mismo, donde se filtran palabras y lenguajes nativos, antroponimias, ritos, indumentaria, divinidades, jerarquías políticas, restos materiales, etc. ${ }^{4}$. No se trata de un sistema cultural cerrado, sino más bien de uno que asume e interpreta la diferencia cultural entre partes heterogéneas que continuamente se entrelazan ${ }^{5}$. El monólogo del conquistador, se convierte en una "polifonía discordante", donde se produce una conversación entre voces heterogéneas y altisonantes que implica nuevos códigos e interpretaciones antes no considerados, un proceso de hibridación cultural entre los contendientes ${ }^{6}$.

A través de un análisis desde la cultura de lo social, se propone lleva a cabo una reconstrucción teórica de la dominación española en los Andes Centrales, especialmente en su forma simbólica-ideológica y su puesta en práctica a través de festividades como el Corpus Christi. Se toma como caso de estudio, la festividad desarrollada en Cuzco, en tanto se considera que la ciudad presenta características

2 Frank Salomon, "Superman es más súper cuando se quita la malla", Chungara, Revista de Antropología Chilena 45-4, (2013): 515-521.

3 Thomas Abercrombie, "To Be Indian, to Be Bolivian: "Ethnic" and "National" Discourses of Identity", en: Nation-State and Indians in Latin America, ed. G. Urban y J. Sherzer (Austin: University of Texas Press, 1991): 95-130.

4 Salomon, "Superman", 517.

5 Abercrombie, "To Be Indian," 96-97.

6 Salomon, "Superman," 520.

Artificios. Revista colombiana de estudiantes de historia. No. 5. Agosto de 2016. ISSN. 2422-118X 
particulares que la hacen un centro preeminente para las autoridades coloniales, para los antiguos linajes incaicos, y para una vasta población indígena. En otras palabras, Cuzco constituyó un ejemplo claro en los Andes de lo que Pratt ${ }^{7}$ denomina una zona de contacto, entendiendo a esta como espacios sociales donde se produce un choque de cultura dispares y donde también se establece una vinculación permanente que implica relaciones extremadamente asimétricas de dominación y subordinación, pero no por ello sin interacción cultural, ni entrelazamiento de cosmovisiones y prácticas.

De esta manera, se intenta una revisión de las problemáticas relativas a la hibridación cultural en el Cuzco colonial del siglo XVII y también de las redes de interacción que ésta implica. Esto permite ampliar el espectro de actores sociales del proceso hacía otros colectivos sociales, menos visibles o homogéneos que las élites (indígenas o hispanas), pero que no pueden ser olvidados para entender el alcance de la imposición española en Andes. Algunas consideraciones sobre la recepción y la reformulación de los sectores subalternos (en doble sentido, de la Corona y de las élites incaicas) permiten relativizar argumentos lineales que consideran los procesos de sincretismo cultural como inherentemente ligados a la acción de las élites dirigentes.

En una visión de corte tradicional, se intentaría aproximarse a las formas dinámicas en que los agentes sociales nativos articulan su experiencia del hecho colonial, entendiendo a este como la imposición de una estructura institucional y administrativa de origen foráneo y también, la adopción de aspectos culturales europeos en las comunidades andinas. Pero invirtiendo la ecuación, también se puede apreciar la progresiva incorporación de elementos prehispánicos en el sistema colonial que implicó un rol no menor de los sectores indígenas.

7 Mary Louise Pratt, “Arts of the contact zone”, Profession, (1991): 34-35. Y Mary Louise Pratt, Imperial eyes: Travel writing and transculturation. (Londres: Routledge, 2008). 1-12.

Artificios. Revista colombiana de estudiantes de historia. No. 5. Agosto de 2016. ISSN. 2422-118X 
A esos fines, en un primer momento, realizaremos un acercamiento teórico sobre el ideal europeo, cortesano y occidental importado por los peninsulares a los Andes. Posteriormente, retomaremos el caso paradigmático del festejo de Corpus Christi en Cuzco en donde se articulan una multiplicidad de variables sociales y culturales que permiten aproximarse a las formas en que se construyeron y legitimaron las hegemonías políticas durante el siglo XVII en el Virreinato del Perú.

\section{Importando cosmovisiones}

\section{La dominación cultural}

La dominación colonial en los Andes Centrales (así como en el resto de los territorios coloniales), incluyó también la imposición de un discurso hegemónico, que a primera vista constituyó un total silenciamiento de las expresiones culturales precolombinas. La irrupción de los ibéricos implicó no sólo la desaparición física de millones de indígenas y la desestructuración socioeconómica del Imperio Inca, sino también un intento por acallar todos aquellos elementos que no pudieran ser adaptados a la cosmovisión europeo-cristiana de los conquistadores. Se trató de un quiebre de la sociedad y cultura prehispánica mediante la imposición de modelos exógenos provenientes de Europa, dimensionados por la sociedad opresora como superiores, lo que redundó en prácticas concretas de asimilación al orden colonial (la materialización de las cosmovisiones a través de elementos como la lengua, la religión, la organización social, etc.). En esa tónica se destruyeron centros ceremoniales prehispánicos para construir iglesias sobre ellos, se impuso el castellano como lengua oficial, se persiguió al paganismo y la idolatría, entre otras cosas.

El recurso crucial para detectar la existencia de protagonistas subalternos al dominio español, los indígenas tanto en sus élites como en sus bas- 
es, surge de las mismas contradicciones del poder colonial ${ }^{8}$.Éstas se constituyen como procesos pluriseculares en donde los resultados son abiertos e inacabados, ya que el poder ejercido desde España no era de ninguna forma absoluto, sino que se hallaba "mediado" por distintas instancias sociales, jurídicas y políticas en donde se debatía y se reformulaban las formas de dominación.

En las sociedades coloniales, la conquista no es un evento singular. La confrontación de sistemas culturales distintos es regularmente creada en los rituales como el locus de su articulación histórica, predominando las formas de la intervención colonial, pese a lo cual los individuos mantienen cierta agencia para definir los términos de la relación entre ámbitos locales y la Metrópoli ${ }^{9}$. En una perspectiva de larga duración, esto se construyó reelaborando los elementos prehispánicos a la luz de los elementos importados y de los condicionantes de las sociedades indias, favoreciendo la consolidación de un nuevo orden social y cultural ${ }^{10}$. Pero a partir de esto, también es posible percibir cómo los indígenas implementaron lógicas de resistencia cultural a través de un maridaje de elementos prehispánicos y coloniales, que dieron lugar a nuevas experiencias identitarias. Como lo entiende Thomas Abercrombie: "resulta irónico que las tácticas de resistencia fueran generadas a través de las múltiples instituciones y doctrinas que los colonizadores impusieron estratégicamente para erosionar el pasado y destruir (precisamente) la resistencia, pero es justamente lo que sucedió; las instituciones y prácticas hispánicas y católicas (y algunos españoles, al menos los sacerdotes) se convirtieron necesariamente para adaptarse a las sociedades indígenas"11.

\footnotetext{
8 Salomon, "Superman," 517.

9 Thomas Abercrombie, "Articulación doble y etnogénesis" en Reproducción y transformación en las sociedades andinas, siglos XVI-XX (Quito:Abya Yala, 1991): 197-212.

10 Marcello Carmagnani, El regreso de los dioses. El proceso de reconstitución de la identidad étnica en Oaxaca, siglos XVII-XVIII (México: Fondo de cultura económica, 1989): 11-28.

11 En el original: "It is ironic that the tactics of resistance should have been developed through the very institutions and doctrines that the colonizers had strategically imposed to erase the past and to destroy resistance, but that is precisely what happened; Hispanic and Catholic institutions and practices (and some spaniards- at least, priests) had become necessary for "indigenous" societies"(Traducción propia).
}

Artificios. Revista colombiana de estudiantes de historia. No. 5. Agosto de 2016. ISSN. 2422-118X 
La agencia de estos sectores indígenas no resulta sin embargo un hecho menor. No solo al evidenciar las imperfecciones del dominio colonial, sino también al incorporar la identidad indígena en una perspectiva histórica, es decir como un fenómeno que al devenir en el tiempo se convierte en una estrategia dinámica, que al mismo tiempo que es condicionada por los marcos institucionales coloniales, también impone sus propias lógicas formatizantes. El acceso de los indígenas a cargos políticos de relativa importancia, la incorporación de cosmologías incaicas a los panteones religiosos cristianos mediante analogías (Cristo/Inti-Rey) o la posibilidad de los grupos subalternos de canalizar sus demandas colectivas (relativas a la explotación económica) a través de los canales legales existentes, evidencia como las estructuras europeas y las indígenas mutan en la práctica hacía formas híbridas y complejas.

\section{El ideal cristiano-cortesano en el Mundo Andino}

Como señala Eugenia Bridikhina con la imposición del sistema colonial en los Andes también se produce el establecimiento de una corte que sirve de modelo a las "clases dirigentes" locales sobre las pautas de conducta y sociabilidad europeas, permitiéndoles percibir la vida política y actuar en ella a través de unos valores cortesanos compartidos en los territorios hispánicos ${ }^{12}$. Con la corte, entonces, se expande un modelo de etiqueta y ritualidad exacerbada, así como el del ideal nobiliario (el modelo del caballero hidalgo), que queda especialmente reflejado en los ritos religiosos.

No se puede comprender la importancia de las festividades como Corpus Christi en los Andes, sin entender el rol de la etiqueta y los ceremoniales como instrumentos de jerarquía y de mantenimiento de distancia. El lugar ocupado en la procesión era un indicador de poder que permitía definir quiénes disfrutan de las situ-

12 Eugenia Bridikhina, "La ciudad y la corte como espacios de poder en Hispanoamérica. La Plata colonial”, Revista de Indias 67- 240, (2007): 554. Y también Eugenia Bridikhina, Theatrum Mundi, entramados del poder en Charcas colonial. (Lima: Instituto Francés de Estudios Andinos, 2007): 207-242.

Artificios. Revista colombiana de estudiantes de historia. No. 5. Agosto de 2016. ISSN. 2422-118X 
aciones más estratégicas dentro de la sociedad. Para Bridikhina ${ }^{13}$ en cada rito los participantes eran portadores de un capital simbólico según su puesto en la jerarquía de la sociedad estamental, en la que el rey ausente ocupaba honoríficamente el máximo lugar. La posición de cercanía o lejanía del centro, así como el uso de ciertos objetos simbólicos, marcaban el lugar privilegiado y, por ende, la fuente de la autoridad.

Las autoridades coloniales que representaban la persona del rey, acentuaban su papel privilegiado por medio de la posesión de bienes simbólicos y ocupando posiciones espaciales diferenciadas durante las ceremonias. El uso de objetos de distinción como la silla, la almohada o el tapete, eran indicadores del honor de un oficio, y de estimación y respeto que podían hacerse extensivos a las esposas y parientes de quienes lo poseían ${ }^{14}$.

Esta teatralización cortesana exigía tener una fachada con todos los signos y modales asociados a la clase social, lo que implicaba un escrupuloso control sobre el cuerpo, los gestos y los vestidos. Ser un cortesano no significaba simplemente poseer y exhibir algo material, sino que implicaba también tener una conducta apropiada a las normas y apariencias que fijaba el grupo social. Se trataba de un ideal de comportamiento social y de un programa individual que permitía elaborar un lenguaje corporal a través del cual se expresaban las relaciones entre los superiores y subordinados, un lenguaje que se expandía de arriba abajo en la sociedad ${ }^{15}$.

Como lo entiende Alejandro Cañeque ${ }^{16}$ la simbólica del poder, no era un elemento efímero y secundario sino parte íntegra de los procesos políticos y de la estructura de poder colonial e imperial, ya que las ceremonias rituales no son una simple operación de cosmética del poder, sino parte integral del mismo y de la política. A su vez, la organización del espacio y la estratificación de las rela13 Eugenia Bridikhina, "La ciudad", 557.

14 Alejandro Cañeque, "De sillas y almohadones o de la naturaleza ritual del poder en la Nueva España de los siglos XVI y XVII", Revista de Indias 64-232 (2004): 609-634. Bridikhina, "La ciudad," 553-569 y Bridikhina "Theatrum," 138-164.

15 Cañeque, "De sillas," 611-633 y Bridikhina “La ciudad," 568-569.

16 Cañeque, "De sillas," 613

Artificios. Revista colombiana de estudiantes de historia. No. 5. Agosto de 2016. ISSN. 2422-118X 
ciones sociales estaban estrechamente relacionadas, en tanto han quedado documentadas numerosas cartas al rey de autoridades coloniales por faltas a la etiqueta esperada de otras autoridades. Virreyes, obispos y oidores podían elevar quejas formales por el uso de un almohadón, o por una falta de cortesía en el saludo ${ }^{17}$. Estas lógicas teatrales y de etiqueta de la vida social colonial, fueron progresivamente adoptadas por las elites nativas para legitimarse y empoderarse como auténticas autoridades étnicas a los ojos de los conquistadores. Su participación en el festejo de Corpus Christi va en la misma tónica; ostentar un puesto destacado en la procesión implicaba que el mismo se trasladaba a los demás ámbitos de las relaciones sociales.

\section{Celebrando el triunfo de Cristo, un acercamiento a las lógicas del Corpus}

Un aspecto sobresaliente en las fiestas coloniales era la omnipresente influencia de la Iglesia Católica como la institución creadora y sancionadora de pautas de comportamiento y valores sociales. Su protagonismo quedaba patente en las ceremonias públicas, y la participación del estamento eclesiástico en la preparación de los elogios, sermones, misas políticas, y en las rogativas para la conmemoración de las victorias militares ${ }^{18}$, como ha quedado reflejado a través de las representaciones artísticas alusivas a las procesiones en Cuzco, en donde los símbolos que aluden a la jerarquía religiosa y política aparecen íntimamente ligados (Ver figura 1).

El Corpus Christi, tal vez la celebración cristiana más importante del calendario litúrgico, al momento de su llegada a América ya tenía una estructura definida, en donde se ponían en juego elementos de corte cristiano-occidental y se actu-

17 Hanke, Lewis (ed.), Los virreyes españoles en América durante el gobierno de la casa de Austria. (México, Biblioteca de Autores Españoles, vol. CCLXXV, 1978):76-78, 81-84.

18 Eugenia Bridikhina "La propaganda política y creación del nuevo lenguaje festivo en los primeros años de la república de Bolivia: rupturas y continuidades", Espacio, tiempo y forma, revista de la facultad de Geografía e Historia Serie V-22, (2010): 236.

Artificios. Revista colombiana de estudiantes de historia. No. 5. Agosto de 2016. ISSN. 2422-118X 
alizaba por medio de una representación simbólica el dominio del Rey de España, y con él, la victoria de la Cristiandad sobre los infieles. En 1573, el Virrey Toledo afirmaba "[L]a fiesta y procesión de Corpus Xpi es la principal que se hace en todo el año, así por lo que representa como por ir en ella el cuerpo de nuestro Señor Xpo, Dios y Hombre verdadero"19. Es conocida ya la preeminencia de Toledo como figura paradigmática del período, por lo cual su testimonio también resulta interesante, en tanto no solo demuestra la centralidad del Corpus Christi como fiesta pública sino también la forma que este debe adquirir para constituirse en un instrumento útil para la consolidación del sistema colonial: "se ha de poner más cuidado en la representación, por ser estos indios plantas nuevas y darles doctrina y empleo para que entiendan y vean lo que es necesario para salvarse, de lo cual vienen en algún conocimiento de las cosas que se les predican y enseñan por el autoridad"20.

En el Corpus, el triunfador es el mismo Cristo encarnado en la hostia, pero en el Perú colonial, la conquista española también formó parte de la representación. Implícitamente los colonizadores celebraron su triunfo militar y su dominación sobre los no cristianos ${ }^{21}$, tal como se ponen en relieve en la serie de oleos que aún se conservan de la época del obispado de Manuel de Mollinedo y Angulo. En ellos se observa una reiterada afirmación de poder simbólico, en donde se teatralizan los signos que representan a una Monarquía triunfante: Cristo aparece intrínsecamente ligado a una configuración poblada de escudos y símbolos reales, mientras todo el complemento de la escena reactualiza el mencionado ideal cortesano de vestimenta y etiqueta.

19 Horacio Urteaga y Carlos Alberto Romero, ed., Fundación española del Cuzco y Ordenanzas para su gobierno. (Lima: Talleres gráficos Sanmartí y cía, 1926), 87-91.

$20 \quad$ Urteaga y Romero, Fundación española del Cuzco, 87-91

21 Carolyn Dean. Inka bodies and the body of Christ: Corpus Christi in colonial Cuzco, Peru. (Carolina del Norte: Duke University Press, 1999): 23-38.

Artificios. Revista colombiana de estudiantes de historia. No. 5. Agosto de 2016. ISSN. 2422-118X 


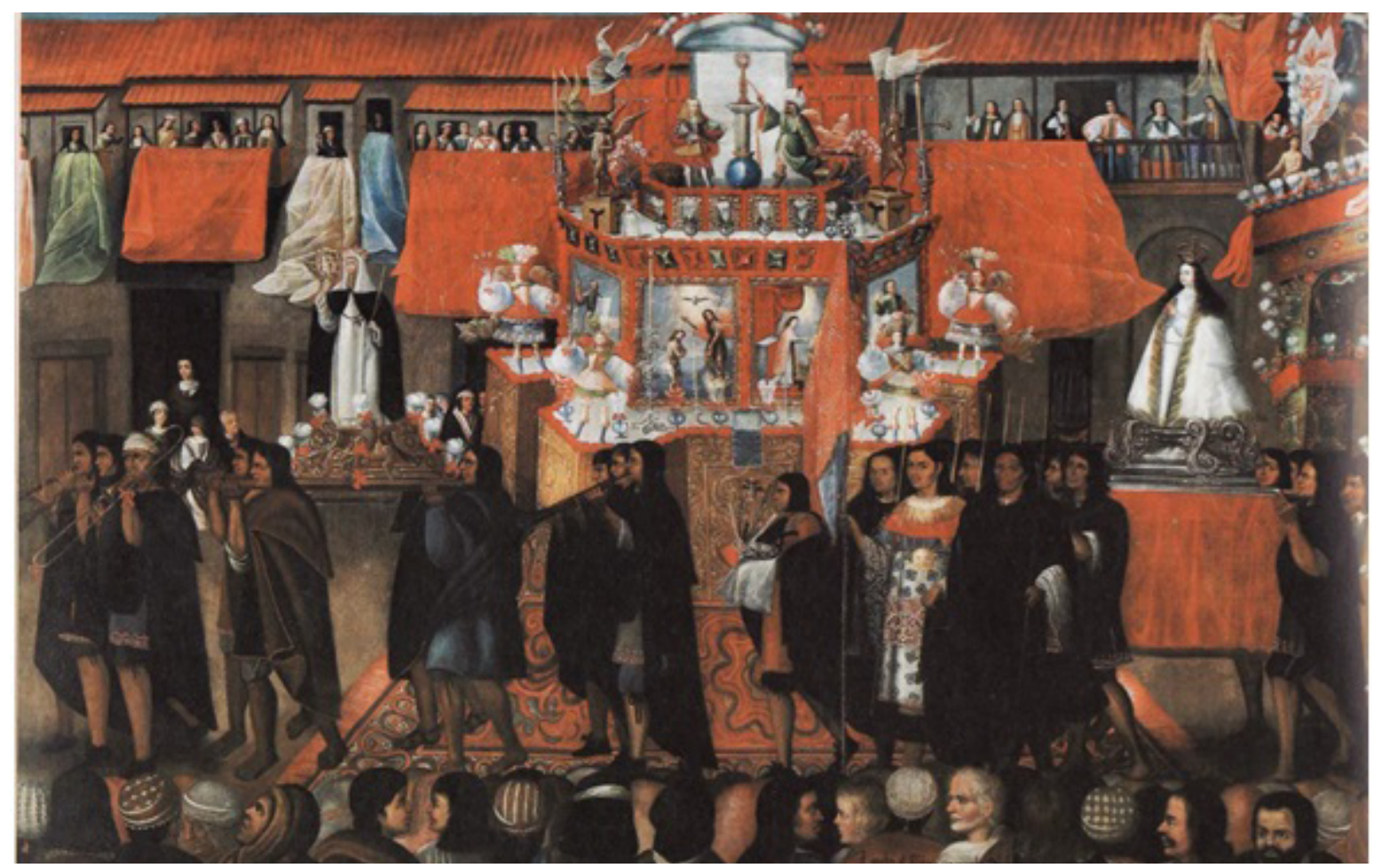

Figura 1- Colección Corpus Christi "Santa Rosa y La Linda" - Museo de Arte Religioso del Palacio Arzobispal de Cusco.

Carolyn Dean ${ }^{22}$ apunta a que la conquista de América fue percibida por aquellos españoles que participaron en ella como una extensión de la Reconquista ibérica. Muchos de los cronistas refieren a los conquistadores como cristianos, no solo haciéndose eco de confrontación entre musulmanes y cristianos, pero apropiando y adaptando al Nuevo Mundo las preconcepciones europeas.

Al llegar a los Andes, el dominio colonial intentó proseguir estas prácticas, en concordancia con el interés de implantar un discurso hegemónico. Sin embargo, tal voluntad no impidió la mutación de la misma, que manteniendo el estatus de primacía en el calendario festivo religioso fue incorporando rasgos prehispánicos hacía su interior. Dentro de la sociedad colonial, el Corpus Christi aparece como un fenómeno de gran importancia analítica, porque permite obser-

22 Dean, Inka bodies, 14.

Artificios. Revista colombiana de estudiantes de historia. No. 5. Agosto de 2016. ISSN. 2422-118X 
var cómo en las formas rituales se relacionan distintos grupos sociales; una articulación entre dominadores y dominados que implica la reformulación de las categorías impuestas por los primeros hacia los últimos, escenificada en los canales porosos por los cuales el ritual adquiere una estructura distinta a la peninsular. La ritualidad de las fiestas coloniales estaba planteada de antemano, en ellas los comportamientos y secuencias aparecían preestablecidos, como una obra de teatro donde todos conocen su desarrollo y su final. Se esperaba que cada agente o actor cumpliera un rol determinado dentro de su posición social, que no era solo poseer un determinado rango sino también demostrar que se ostentaba un rango a través del comportamiento, los modales, la vestimenta y los signos de posición coloniales $^{23}$. Aún así, el festejo no era solo una celebración, sino también una forma de transculturación en él están presentes los grupos subordinados seleccionando y reconfigurando en sus propios cánones las influencias de la cultura dominante ${ }^{24}$.

La presencia de grupos indígenas se entrelaza en dos niveles: en primer lugar, la afirmación de la dominación aparecería menos consolidada de lo esperado, en tanto un selecto número de individuos teatraliza las tradiciones incaicas en la puesta en escena de la procesión (ver figura 1), lo cual induciría a pensar cómo los mismos sujetos subalternos utilizan y reformulan su propia identidad insertándose en un ritual hispánico. En segundo lugar, hacia el interior de estos grupos indígenas pueden encontrarse diferencias sustanciales. En otras palabras, se observa la presencia de una élite étnica privilegiada, descendiente de los antiguos soberanos incas que adquiere preeminencia en las celebraciones y también, sectores subsumidos de la población, que están interactuando desde los márgenes del festejo. Es importante reparar en esta participación, si bien marginal no por eso menos importante, que supone la agencia de éstos grupos subalternos en la recepción-reformulación de la experiencia derivada

23 Eugenia Bridikhina, "La ciudad," 556-569.

24 Pratt, “Arts of the Contact Zone," 36. Y Pratt, Imperial eyes, 1 1-12.

Artificios. Revista colombiana de estudiantes de historia. No. 5. Agosto de 2016. ISSN. 2422-118X 
del hecho colonial.

\section{¿Una cosmovisión hegemónica? La porosidad del dominio colonial}

Tal como lo entiende E.P. Thompson "lejos de tener la permanencia fija que sugiere la palabra tradición, la costumbre era un campo de cambio y de contienda, una palestra en la que intereses opuestos hacían reclamaciones contrarias"25. Podemos entender entonces como la instauración de festejos cristianos como el Corpus Christi no queda al margen de tensiones, mixturas y reapropiaciones culturales. La cultura y con ella sus componentes: los ritos, las formas simbólicas, los atributos culturales de la hegemonía, la transmisión intergeneracional de costumbres, y la evolución en el tiempo de las costumbres es necesariamente una plataforma de conflictos entre lo cristiano y lo pagano, lo colonial y lo indígena, lo tradicional y la innovación.

El poder colonial se encontraba en las personas que se erigían como autoridades, en los elementos carismáticos de las formas de liderazgo personal, y con ello íntimamente ligado a la pompa y a las exhibiciones públicas de poder. La conexión que existía entre presencia de la majestad (a través de sus representantes coloniales) y ejercicio del poder no podía sobrevivir la transferencia de autoridad a la acción puramente impersonal del Estado moderno ${ }^{26}$.

Es necesario destacar que un aspecto intrínseco de las sociedades pre-modernas fue una notable carencia, a nivel local, de medios de coerción directa por parte de los gobernantes (las fuerzas regulares de policía eran prácticamente inexistentes). En la monarquía absoluta, la legitimidad radica en la existencia física del rey, y no en sistemas de vigilancia continua, por lo cual la autoridad del soberano absoluto debe

25 Edward Palmer Thompson. Costumbres en común: estudios en la cultura popular tradicional. (Barcelona: Crítica, 1991), 19.

26 Cañeque, "De sillas," 610-628.

Artificios. Revista colombiana de estudiantes de historia. No. 5. Agosto de 2016. ISSN. 2422-118X 
basarse en espectaculares y teatrales intervenciones de poder, como es el caso de los castigos ejemplares, más una forma de mantener simbólicamente el statu quo social que una práctica cotidiana, da cuenta el clásico ejemplo de la extirpación idolátrica de Taqui Onkoy ${ }^{27}$. En una sociedad donde la mayoría de sus miembros no sabía ni leer ni escribir, las representaciones teatrales y simbólicas del poder poseían una importancia fundamental, era el lenguaje del poder que todo el mundo podía entender ${ }^{28}$.

El poder político colonial, tal como se ejercía en el cuerpo social era un poder muy discontinuo. La diversidad de pueblos que incluía la dominación colonial, con culturas y regímenes particulares hacía muy difícil un control efectivo por parte de la Metrópoli, con lo cual el poder que la Corona ejercía sobre sus súbditos era limitado. Las mallas de la red colonial eran muy grandes y permeables, en tanto que un número casi infinito de cosas, de elementos, de conductas, de procesos escapaban al control del poder hispano. Entonces aun cuando las élites indígenas participaran como un miembro aceptado de la procesión en su rol de líderes étnicos subordinados a la autoridad colonial, sus reivindicaciones, atuendos, lógicas y significados están poniendo en tela de juicio la dominación española, y empoderándose como autoridades étnicas ${ }^{29}$.

Debido a la imposibilidad de lograr un control total sobre la población andina, y por ende de lograr una homogeneización cultural, ciertos elementos fueron escogidos como formas de someter la alteridad étnica al dios cristiano (como las danzas y los cantos). Los españoles experimentaron una contradicción, por un lado, la necesidad de estimular la mímesis y enmarcar dentro de las lógicas coloniales a los colonizados, y por otro lado, defender y legitimar su superioridad en la jerarquía colonial. Pero, así como la representación implica el sometimiento a la cultura del conquistador, también implica su pervivencia cultural, una necesaria alteridad opuesta a

27 Samuel Villegas, "El movimiento del Taqui Onkoy (Huamanga, siglo XVI)”, Investigaciones Sociales, 15(26), (2011): 115-130.

28 Cañeque, "De sillas," 613.

29 Dean, Inka bodies, 97-159.

Artificios. Revista colombiana de estudiantes de historia. No. 5. Agosto de 2016. ISSN. 2422-118X 
la del conquistador, y una forma de resistencia que no está eximida de $\operatorname{conflictos}^{30}$.

Ahora bien, las tradiciones andinas no eran fácilmente extirpables, aún a inicios del siglo XVII los nativos seguían rindiendo culto a las huacas ${ }^{31}$. La comprensión de los códigos andinos por los conquistadores era parcial, por tanto, no siempre llegaban a comprender lo representado ${ }^{32}$. Es en este punto quizás, donde la presencia de sectores subalternos hacía el interior de las mismas comunidades indígenas, es decir, ese grupo heterogéneo que no pertenecía a la élite de descendencia inca, puede ser más palpable. Los registros de los procesos de extirpación de idolatrías del siglo XVII dan cuenta de una gran pervivencia de tradiciones prehispánicas hacía el interior de éstos grupos, muchas veces en un carácter doméstico o local. De esto da fe, entre otros, el manual de extirpación de idolatrías de José de Arriaga (1621) [...] "Después de las huacas de piedra la mayor veneración, y adoración es la de sus mallquis que en los llanos llaman munaos, que son los huesos o cuerpos enteros de sus progenitores gentiles" ${ }^{\prime 3}$.

La preeminencia de este tipo de práctica, cuya raigambre en muchos casos se puede remontar incluso antes del período incaico, señala la permanencia de la cosmología andina del culto a los ancestros. Los cuerpos de los progenitores (mallquis) no eran cuerpos muertos, sino uno de los tipos de corporalidad en las que se manifiestan los antepasados. Son antepasados sagrados, y son presencias vivientes que refuerzan la organización social, política y religiosa. Excedería

30 Berta Ares Queija "Las danzas de los indios: un camino para la evangelización del virreinato del Perú", Revista de Indias 44-174, (1984): 450-463. Y Dean, Inka bodies, 46-96.

31 Cristóbal de Albornoz [ca. 1584], "Instrucción para descubrir todas las guacas del Pirú y sus camayos y haziendas": (Arriaga 1920:42 [1621: Capítulo IV]). Y Francisco de Ávila 2002 [1646] "La Epifanía del señor y pascua de los Reyes". En Gerald Taylor. Sermones y ejemplos. Antología bilingüe castellano-quechua Siglo XVII. Vol 17, (IFEA -Lluvia Editores, Lima, 2002): 50-51.

32 Jaime Valenzuela Márquez, “... que las ymagenes son los ydolos de los christianos” Imágenes y reliquias en la cristianización del Perú (1569-1649), Jahrbuch für Geschichte Lateinamerikas 43, (2006): 41-66.

33 Arriaga, Pablo José de (1984) Extirpación de la idolatría en el Perú. Edición de María Isabel Balducci. CONICET, Buenos Aires [1621]. Citado por Maria Alba Bovisio, "Los muertos, otra corporalidad: acerca del imaginario sobre la muerte a través de las fuentes de extirpación de idolatrías (siglos XVI y XVII)". Actas del VI Congreso Internacional de Etnohistoria, FFyL, UBA, Buenos Aires, 6, (2005): 8.

Artificios. Revista colombiana de estudiantes de historia. No. 5. Agosto de 2016. ISSN. 2422-118X 
al presente trabajo pensar cómo la larga duración de estas prácticas estrechamente ligadas a la identidad comunitaria de estas sociedades indígenas funciona como elemento articulador frente al hecho trascendental y desestructurador de la Colonia.

A nivel de las élites, el Corpus incluía en la procesión a partir del siglo XVII a los soberanos incas y triunfando sobre ellos al soberano de España, simbolizando el mando del monarca español sobre los Andes. En 1610, pocos años luego del fin de la resistencia de los Incas de Vilcabamba (1570), los Incas aparecían legitimando su estirpe real en una celebración religiosa española. Significativamente los representados iban desde Manko Qhapac, el mítico fundador del imperio incaico, hasta Atahuallpa, último Inca prehispánico tal como señala Bartolomé Arzáns de Orsúa y Vela ${ }^{34}$ “con toda majestad venían de dos en dos todos los monarcas ingas hasta el poderoso Atahuallpa" ${ }^{35}$. En tal representación se dejaba de lado a los líderes que se declararon rebeldes al dominio español; ambiguamente la autoridad colonial permitía el reconocimiento a jefes étnicos, pero impedía la reivindicación de aquellos que más violentamente chocaron contra los intereses coloniales ${ }^{36}$.

Para la segunda mitad del siglo XVII las élites cuzqueñas seguían desfilando como continuadoras de la realeza Inca, pero ya no representando a personas específicas del pasado y reclamando autoridad de manera indirecta, ahora lo hacían figurándose ellos mismos como los soberanos, en tanto que el gobierno colonial autorizaba a estos miembros de las élites a mostrarse como los legítimos descendientes de los reyes incas. Cuando los Incas rememoraban su pasado Real, aun cuando se tratara de una realeza étnica, se empardaban simbólicamente con la Corona española ${ }^{37}$. Y así lo re-

34 Extraído de: Dean, Inka bodies, 130.

35 Lógicamente dejaba al margen a todos los soberanos posteriores a la llegada de los españoles, negando a los Incas de Vilcabamba.

36 Dean, Inka bodies. 97-121.

37 Dean, Inka bodies. 97-121.

Artificios. Revista colombiana de estudiantes de historia. No. 5. Agosto de 2016. ISSN. 2422-118X 
tratan cinco de los oleos de la serie de Corpus (1674-1680) que Bernales Ballesteros ${ }^{38}$ denomina como "Santiago," "San Sebastián," "Virgen de Belén," "San Cristóbal," "Santa Rosa y La Linda."

\section{La andinización del Corpus}

Ya desde tiempos del Virrey Toledo el Corpus era el festival religioso más importante de Cuzco, en el cual se intentaba mostrar a los recientemente cristianizados indígenas, la superioridad de Cristo por sobre sus tradiciones e idolatrías. Las similares fechas de realización entre Corpus Christi y el Inti Raymi otorgaron una oportunidad a los españoles de aprovechar el festejo nativo al solsticio de invierno como un elemento más del ritual.

Como lo entiende Juan Polo de Ondegardo ${ }^{39}$ al referirse al Inti Raymi "ase de advertir que esta fiesta cae quasi al mismo tiempo que los Christianos hazemos la solemnidad de Corpus Christi, y que en algunas cosas tienen alguna apariencia de semejanza (como es en las danzas, representaciones ó cantares) y que por esta causa á auido y ay oy dia entre los Indios que parecen celebrar nuestra fiesta de Corpus Christi, mucha supersticion de celebrar la suya antigua del Intiraymi."

Al igual que Guaman Poma de Ayala ([1615]1988, 220-221) "Este es hazian la moderada fiesta del Ynti Raymi y se gastaua mucho en ello y sacrificauan al sol. Y enterraua al sacrificio llamado capac cocha que enterrauan a los niños ynocentes quinientos y mucho oro y plata y mullo" (ver figura 2).

$38 \quad$ Jorge Bernales Ballesteros, "El Corpus Christi: Fiesta barroca en Cuzco," Actas de las I jornadas de Andalucía y América, II (1981): 275-290.

39 Juan Polo de Ondegardo, "Relación de los fundamentos acerca del notable daño que resulta de no guardar a los indios sus fueros" en Colección de Libros y Documentos referentes a la Historia del Perú, 1, ([1571] 1916), serie No 3.

Artificios. Revista colombiana de estudiantes de historia. No. 5. Agosto de 2016. ISSN. 2422-118X 


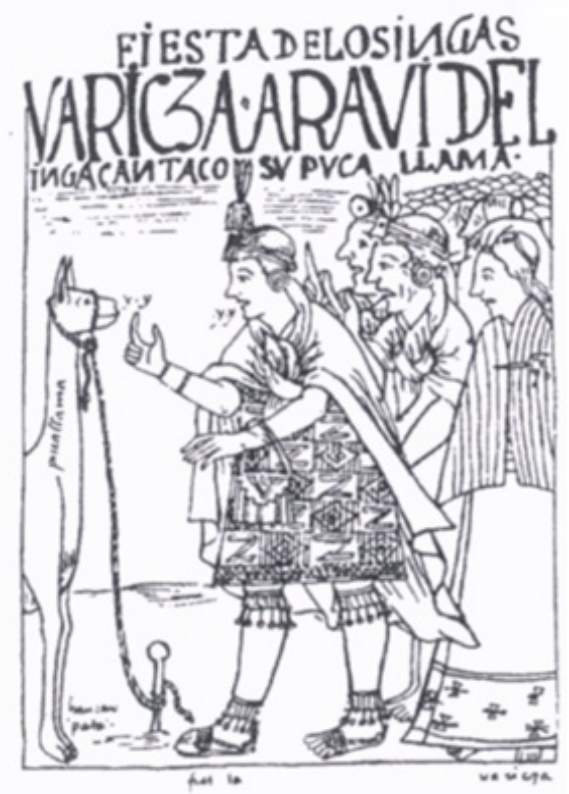

Figura 2- tomada de F. Guamán Poma de Ayala "Fiesta de los ingas" en Nueva coronica y buen gobierno[1584-1615] (Transcripción, prólogo, notas y cronología de Franklin Pease García)

En este punto, la necesidad de encontrar una vía rápida para la evangelización indígena, llevó a que la deidad solar andina se reconvirtiera al monoteísmo, variante que convenía a los intereses católicos en su necesidad de equiparar un dios andino creador con el Dios cristiano. Se permitía a los indígenas realizar sus rituales de celebraciones (cantos, danzas, ofrendas) mientras el dogma cristiano no fuera cuestionado. La identificación del Dios cristiano como luz no era ajena al hombre español, que por tradición medieval, estaba acostumbrado a imaginar lo divino en términos luminosos. En Cuzco el Corpus fue aún más importante porque era el triunfo de la cristiandad sobre el imperio Inka y sobre su Dios, el Sol. Cristo era transformado no solo en un cuerpo triunfante sino también en el nuevo Inti. El Inti Raymi fue reemplazado por Corpus Christi, pero ambos festejos siguieron inextricablemente unidos simbólicamente ${ }^{40}$.

40 Dean, Inka bodies, 46-62 y Leontina Etchelecu “Diversas formas que adopta la religión andina. YuxArtificios. Revista colombiana de estudiantes de historia. No. 5. Agosto de 2016. ISSN. 2422-118X 
En la Conquista temprana, ya son observables los debates hacía el interior del grupo español sobre un "primitivo cristianismo" presente en los Andes. Este interés en la religiosidad andina derivó en la traslación de conceptos ajenos en términos más familiares, ya sea consciente (para establecer un terreno común a los lectores) o inconscientemente (porque el propio etnocentrismo impedía que captaran una realidad extraña en sus propios términos). ${ }^{41}$ Es destacable el esfuerzo español por buscar pruebas en la cosmología incaica de la presencia de un dios cristiano antes de la Conquista, a fin de anticipar y legitimar su propia empresa allí, así como también como forma de explicar algo de la grandeza y signos de civilización encontrados en los Andes ${ }^{42}$.

Por otro lado, y según apunta Valenzuela $M_{\text {árquez }}^{43}$ el tercer concilio limense (1582-83) fomentó al uso de las imágenes sagradas entre los medios que propendieron a facilitar la adquisición de la fe por medio de los sentidos, lo cual más tarde sería reforzado con la estética barroca. Las imágenes ofrecían un canal de transmisión doctrinal de alto impacto psicológico y de mayor eficacia pedagógica que el adoctrinamiento textual o verbal, actuando incluso como soporte complementario del catecismo. Signo y significado tendieron a confundirse, haciendo que la imagen se fundiera con su referente celestial y fuera percibida como una verdadera "presencia" divina. Esta confusión fue tanto más patente en el caso de las reliquias, por el hecho de constituir una materialización aceptada de dicha presencia; de ahí que los indígenas se preguntaran si no eran los cristianos tan idólatras como ellos ("Y que las ymagenes son los ydolos de los Christianos" ${ }^{44}$ ).

taposiciones peligrosas", Hispania sacra 59-119, (2007): 296.

41 Thomas Abercrombie. Caminos de la memoria y del poder. Etnografia e historia en una comunidad andina, (Bolivia: Sierpe publicaciones, 2006): 286.

$42 \quad$ Abercrombie, Caminos de la memoria y del poder, 302

43 Valenzuela Márquez, “... que las ymagenes,” 55.

44 "Instrucion contra las cerimonias, y ritos que usan los indios conforme al tiempo de su infidelidad": Confessionario para los curas de indios (Lima 1585) (nota 38), anexo, pp. 253-262, aquí: cap. VI, p. 5v. (cita tomada de Valenzuela Marquez, 2006:55).

Artificios. Revista colombiana de estudiantes de historia. No. 5. Agosto de 2016. ISSN. 2422-118X 
Para los españoles fue importante no solo que los indios participaran en el ritual, sino que también lo hicieran en su condición de nativos sobre los cuales el cristianismo triunfaba. Previo a esto se debía divorciar la representación andina de las creencias andinas: la forma de representación de una danza por ejemplo era la misma o similar a la original incaica, pero su significación estaba claramente subordinada a demostrar la superioridad del cristianismo sobre cualquier otra religión o costumbre ${ }^{45}$. El canto y el baile estaban íntimamente relacionados con la memoria andina, por lo tanto, prontamente éstas cayeron en sospecha y sujetas a la categoría de idolatría y error nativos. Esta situación de persecución provocó una explosión de creatividad en la que los cantos, ritos y narraciones salieron al frente para recapturar el pasado andino o para revisarlo en conformidad con las nuevas formas de constituir colectividades ${ }^{46}$.

Los indios pudieron seguir realizando algunas de sus tradicionales danzas, pero el Sol fue sometido al poder y al triunfo de Cristo. Las representaciones de batallas siempre incluían un grupo relativamente desordenado de incas que era vencido por ibéricos, restableciendo simbólicamente el orden que imponía el sistema colonial, y como una forma de recordar la superioridad europea sobre la americana ${ }^{47}$.

Nuevamente, nos encontramos con indicaciones difusas de grupos pequeños, no necesariamente de élites participando en el festejo, como en su Historia General del Perú ${ }^{48}$ que señala como la celebración implicaba la pervivencia de las prácticas indígenas "ocultas" o "semi-cristianizadas", en las cuales los indios "tenían dedicadas ciertas mantas, vestidos y aderezos, que sólo servían en ella, y así cubiertas las cabezas, andaban en procesión muy despacio, sin hablar uno con otro, tocaban sus tambores. Esto duraba un día y una noche, y al día siguiente comían y bebían en

45 Queija, "Las danzas," 445-463, Dean, Inka bodies, 23-63 y Etchelecu "Diversas formas," 297-301. 46 Abercrombie, Caminos de la memoria y del poder, 278.

47 Dean, Inka bodies, 13-45 y Iris Gareis "Los rituales del Estado colonial y las élites andinas", Bulletin de l'Institut français d'études andines 37-1, (2008): 97-109.

48 Manuel Ballesteros Gaibrois, ed., Colección Crónicas de América. (Madrid: Historia 16, 1987) 453.

Artificios. Revista colombiana de estudiantes de historia. No. 5. Agosto de 2016. ISSN. 2422-118X 
grandísima abundancia, dos días con sus noches, danzando y bailando y diciendo que su oración había acepta al Sol y al Hacedor, y que por eso se holgaban y alegraban, y hacían fiesta en demostración de su contento. El día de hoy, al disimulo en las fiestas del Corpus Christi, traen a la memoria de esta fiesta del ytu, aunque variando las ceremonias por no ser descubiertos; pero en efecto ya se van poco olvidando".

Lo anterior nos plantea una serie de cuestiones importantes para el análisis, las cuales ya fueron esbozadas anteriormente. En primer lugar, notamos como en Cuzco conviven las prácticas rituales incaicas, como el culto al Sol, en estrecha relación con los marcos simbólicos de la cristiandad. De más relevancia es la presencia periférica de estos indígenas y de la voluntad de seguir manteniendo su identidad, al margen de la dominación española. La relativa ineficacia del discurso colonial, como ya se mencionó, por homogeneizar la identidad india consolidó un proceso de hibridación cultural extremadamente complejo.

La acción de las élites étnicas por insertarse en el entramado de poder que instauró la Corona, no es un factor menor para acercarse al mestizaje y a sus consecuencias. Empero, no deja de ser un enfoque sesgado de la acción de los grupos subalternos, en tanto desdibuja la experiencia del grueso de las comunidades indígenas que participaron activamente de este proceso, constituyendo también su propia conciencia. Los cambios introducidos con la llegada de los españoles fueron vividos como una clave irreversible, pero a su vez, dinamizaron la formulación de estrategias, resistencias y adaptaciones muy diversas, que de ningún modo pueden ser entendidas como parte de un grupo reducido de descendencia incaica.

A su vez, el universo andino se refleja en los códigos estéticos de vestimenta, pero en el cual se observa una "europeización" en las modas de las élites cuzqueñas, adoptada a la cosmovisión andina. Es decir, simultáneamente se trata de mostrar que son andinos y soberanos incaicos, pero también que son católicos y que respetan a 
la autoridad colonial (ver figura 1) ${ }^{49}$. Las múltiples referencias al sol en los trajes y atuendo de los curacas cuzqueños se pueden interpretar como reafirmación del culto solar, el cual ya había jugado un papel importante en las religiones andinas. Las referencias al sol igualmente pueden ser vistas como alusiones al imperio incaico, lo cual en la antigua capital del imperio, no sería nada sorprendente, lo cual no entra en contradicción con la asociación de la luz, lo divino y el Dios cristiano. La festividad les proporcionaba a las élites sobre todo un espacio para la escenificación de su rol en la sociedad colonial ${ }^{50}$, de lo cual nos deja interesantes restos las imágenes de Guamán Poma (ver figura 3).
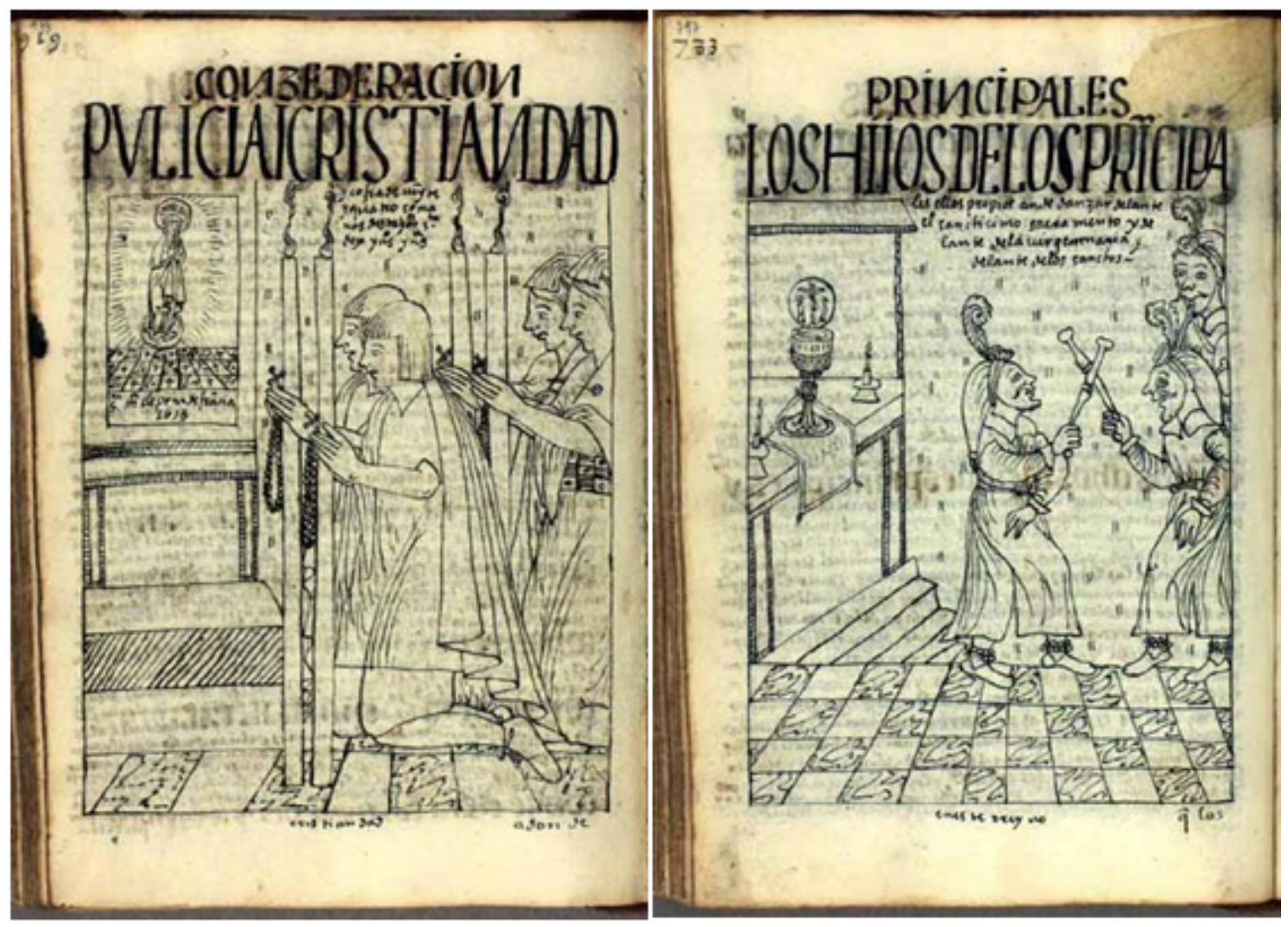

Figuras 3- Tomadas de Guamán Poma, Nueva Coronica y Buen Gobierno.

\footnotetext{
49 Dean, Inka bodies, 122-159.

50 Gareis, "Los rituales," 98-105
}

Artificios. Revista colombiana de estudiantes de historia. No. 5. Agosto de 2016. ISSN. 2422-118X 
Por su parte ya desde 1551 Garcilaso de la Vega ${ }^{51}$ deja registro del acompañamiento del Corpus con música andina, donde las danzas y los distintos cantos servían como un distintivo territorial étnico. La música era parte tradicional de todos los eventos del calendario litúrgico, y reflejo de ello son las numerosas fuentes escritas que dan fe de pagos, contratos y formación de músicos y coros en las iglesias y capillas. A su vez algunos de los lienzos conservados de la serie del Corpus como el llamado "Santa Rosa y La Linda" apunta a cómo la música estaba naturalmente presente en el festejo del Corpus, representando músicos e instrumentos europeos (más no andinos). No necesariamente debemos entender estas pinturas como una representación literal de la procesión, sino que la ausencia de flautas y tambores andinos pueden ser considerados como una búsqueda de asociación al prestigio de lo europeo en las pinturas ${ }^{52}$ (Ver figura 4).

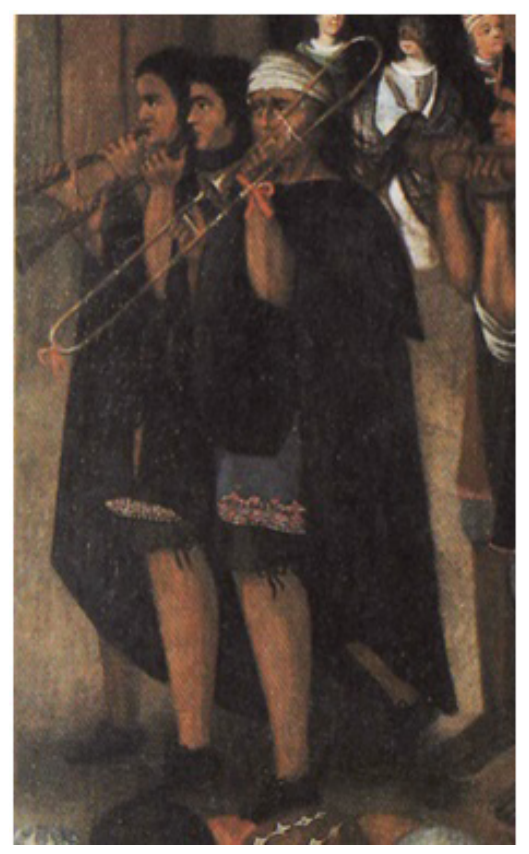

Figura 4- Detalle de trombonista en el lienzo "Santa Rosa y La Linda". Museo de Arte Religioso del Palacio Arzobispal de Cusco.

$51 \quad$ AA.VV. Historiadores de Indias (España: Oceáno, 1999), 73-157.

52 Geoffrey Baker, "Music at Corpus Christi in colonial Cuzco", Early music 32-3. (2005): 365.

Artificios. Revista colombiana de estudiantes de historia. No. 5. Agosto de 2016. ISSN. 2422-118X 
Amediados del siglo XVI, se celebraron grandes fiestas del Corpus en el Virreinato, con la intervención de las élites andinas, donde se estrenaban obras dramáticas que giraban en torno a la Conquista y a la muerte del Inca. Algunas de aquellas obras fueron incluso representadas en quechua y los curacas desempeñaron un papel importante en estas fiestas. El protagonismo de las autoridades andinas, de todos modos, aún no era tan notorio como lo fue en las fiestas del Corpus del Cuzco en la segunda mitad del siglo XVII ${ }^{53}$.

Comolo entiende Leontina Etchelecu ${ }^{54}$ la festividad cristiana era un despliegue de los bailes y cánticos de raíz incaica que habían sobrevivido, a pesar de estar la población sojuzgada cultural, militar, política y económicamente. Pero a medida que la extirpación alcanzaba a sus viejas tradiciones, iba suprimiendo espacios ocupados por un ceremonial nativo que servía de engranaje a esa sociedad andina basada en los lazos de reciprocidad y redistribución. El vaciamiento del ritual garante del pacto, necesitaba ser reemplazado por otra modalidad que asegurara la continuidad de la solidaridad entre sus miembros.

Podemos considerar entonces la participación y el rol desempeñado por los actores en Corpus Christi en función de una puja de poderes simbólicos y de status. Como lo entiende Michel Foucault el poder adopta formas heterogéneas y diversas, como una entidad externa e independiente a la existencia de los sujetos, sino como una acción derivada de los mismos ("el poder no se posee, el poder se ejerce") y por lo tanto de lo que podemos hablar es de relaciones de poder, entre gobernantes y gobernados, gobernantes y elites, elites y pueblo grueso, etc. ${ }^{55}$.

\section{La hibridación cultural, andinos hispanizados}

Las élites incaicas se incorporaron poco a poco a la sociedad colonial, ocupando el nivel superior entre la población indígena y cumpliendo con una función similar a la que

53 Gareis, "Los rituales," 98-106.

54 Etchelecu, "Diversas formas," 298.

55 Michael Focault "Las redes de poder", Farenheit450 1, (1986): 3-4.

Artificios. Revista colombiana de estudiantes de historia. No. 5. Agosto de 2016. ISSN. 2422-118X 
prevalecía antes de la conquista española. Especialmente en el Cusco, las élites del antiguo imperio incaico siguieron teniendo mucho respaldo de la población indígena ${ }^{56}$.

Cumpliendo con su función de intermediarios entre los centros de poder y los pueblos indígenas, fueron ellos quienes reclutaban la mano de obra para las diversas empresas del estado incaico y posteriormente del Estado colonial. Por eso, los curacas jugaron un rol de suma importancia en la organización económica del virreinato peruano. Consecuentemente muchas medidas del Estado colonial apuntaban en especial a la integración de las élites autóctonas en el sistema colonial, por ejemplo la educación de los hijos de las autoridades andinas, que a partir de principios del siglo XVII se llevó a cabo en colegios especiales ${ }^{57}$.

Había una estrecha vinculación de lo religioso con el ámbito político, y una muy elaborada vida ceremonial que funcionaba como eje de interrelación entre estos ámbitos. Es decir, los rituales políticos proporcionaron, de cierto modo, un lugar para negociar las relaciones entre los diversos grupos de la sociedad ${ }^{58}$. Las autoridades políticas indígenas fueron el eje entre las instituciones coloniales y la población. Al comunicar la política colonial a la población del virreinato peruano, los rituales fueron un eje importante en la articulación del poder en los Andes. Las autoridades nativas debían por un lado adecuarse a los cánones de estética y teatralidad coloniales, pero por otro no podían dejar de tener que legitimar su posición como líderes étnicos, a través del idioma, los cultos al sol y las huacas ${ }^{59}$.

A mediados del siglo XVII la nobleza incaica del Cuzco largó un contraataque contra aquellos grupos que desafiaban su autoridad, derechos y privilegios. Una de esas acciones fue incrementar la presencia como sober-

\footnotetext{
56 Gareis, "Los rituales," 98-99.

57 Gareis, "Los rituales," 105-106.

58 Gareis, "Los rituales," 98.

59 Luis Millones "Las ropas del Inca: Desfiles y disfraces indígenas coloniales”, Revista de crítica literaria latinoamericana 21-41, (1995): 55-56 Y Gareis, "Los rituales,” 103-104.
}

Artificios. Revista colombiana de estudiantes de historia. No. 5. Agosto de 2016. ISSN. 2422-118X 
anos incaicos en las festividades coloniales, como demuestran numerosas pinturas contemporáneas. De esta manera se refrescaba la memoria de un pasado glorioso, que legitimaba la posición de autoridad de ese momento ${ }^{60}$. Para fines del siglo XVII esta élite comenzaría a ser llamada como los Incas de maskapaycha (una borla color escarlata que representaba la autoridad inca). La borla escarlata pasó a simbolizar en las festividades como Corpus Christi una ascendencia a la familia real incaica, sin cuestionamientos ${ }^{61}$. Ser un Maskapaycha claramente era un esfuerzo de estas élites nativas coloniales de asegurar y afirmar su posición como legítimos representantes étnicos, y descendientes del linaje Real Inca. En sintonía con esto iban sus esfuerzos por representarse como tales en las festividades religiosas. Testimonio de esto encontramos en un descendiente del linaje real cuando apuntaba "y sin rrepungnancia alguna en todas las funciones publicas se an puesto la insignia de la mascapaicha de vorla colorada que es permitida solo a los que son legitimamentte nobles" (Ver figura 5).

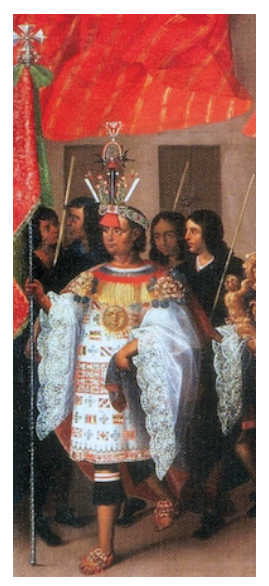

Figura 5 - Detalle de cacique en el oleo "San Sebastian" - Museo de Arte Religioso del Palacio Arzobispal de Cusco

$60 \quad$ Dean, Inka bodies, 63-96.

61 Dean, Inka bodies, 129-130.

Artificios. Revista colombiana de estudiantes de historia. No. 5. Agosto de 2016. ISSN. 2422-118X 
No solo la representación era un símbolo de status, también implicaba materialmente que esas figuras estaban libres de impuestos y tributos. Ya desde el mando virreinal de Francisco de Toledo, los caciques estaban exentos de tributar a la corona, y la desarticulación progresiva del entramado pre colonial, llevó a que este puesto sea codiciado por más grupos o familias, que las que tradicionalmente los ostentaban en el pasado ${ }^{62}$.

Esto no estaba exento de disputas intra-étnicas, por lo cual, muchas veces distintos ayllus se disputaban el derecho a ser los legítimos descendientes de la realeza, y sus consiguientes beneficios. Por ejemplo: Las disputas de las élites cuzqueñas con Cañaris y Chachapoyas en la segunda mitad del SXVI o el conflicto entre los ayllus yacanoras y sucsos en 1655. A lo largo del SXVII las disputas llevaron a la generación de mecanismos de exclusión para determinar quienes estaban habilitados a representarse como Maskapaychas ${ }^{63}$.

\section{Consideraciones finales}

El mestizaje cultural como se ha observado, surge en el siglo XVI en la confluencia de temporalidades distintas (la del occidente cristiano y las de los mundos amerindios), poniéndolas brutalmente en contacto. La irrupción de las mezclas sacude la representación de una evolución única del devenir histórico, y resalta las bifurcaciones, travesías y atolladeros que se van dando en la arena de la historia y dentro de las cuales los agentes sociales se desarrollan y llevan a cabo su vida cotidiana ${ }^{64}$.

En los Andes, la hegemonía española se nutrió y reprodujo a través de la imposición de nuevas formaciones políticas, asentamientos y puestos de autoridad civil, y a través de la teatralización de las relaciones públicas y de rituales mediante los

$62 \quad$ Dean, Inka bodies, 122-159.

63 Dean, Inka bodies, 104.

64 Serge Gruzinski. El pensamiento mestizo. Cultura amerindia y civilización del renacimiento (Barcelona: Paidós, 2007): 75-103.

Artificios. Revista colombiana de estudiantes de historia. No. 5. Agosto de 2016. ISSN. 2422-118X 
cuales los andinos habrían de expresar públicamente su sumisión al dominio colonial ${ }^{65}$. En el pasado pre-colonial, y esto queda plasmado con las alusiones al sol, el Dios Inti, fue reconfigurado por los conquistadores para acoplarlo de manera subordinada al marco conceptual cristiano, produciéndose un proceso de hibridación cultural entre lo andino y lo católico. Es plausible afirmar que el festejo andino del Corpus Christi dejó de ser una tradición europea para convertirse en una tradición mestiza, en donde los actores trataron de adaptar la festividad a sus propias lógicas y necesidades.

De lo trabajado se desprende que la transfiguración de los incas coloniales en sus homónimos imperiales implica una ruptura con el universalismo de la divinidad y la autoridad cristiana, ya que lo que antes estaba subyugado a la voluntad hispánica en ese momento se convertía en étnico, profano, y andino; aun cuando esta evocación al pasado amenazara o fuera vista como una amenaza a la autoridad colonial, es un reflejo de la práctica cotidiana en lo ceremonial. En vastas áreas de los Andes la autoridad colonial era ejercida por subalternos indígenas, de familias tradicionalmente pertenecientes a las élites andinas. Esto simbólicamente (y en ocasiones directamente) impugnaba y/o tensionaba la autoridad colonial.

Las consecuencias de esto pueden observarse en dos niveles de análisis, que, corresponden a la élite indígena y a la comunidad en sentido amplio, es decir, aquellos sectores indios que no correspondían necesariamente a una descendencia real pero que, sin embargo, compartían un acervo cultural común.

Si bien estos grupos "doblemente" subalternos (sujetos de la Corona y de los dirigentes étnicos) aparecen difusamente en las fuentes, por lo tanto el acceso a su experiencia resulta más bien esporádico y fragmentado, no por eso adquieren menor relevancia. Al estar insertados en prácticas económicas, sociales y rituales de filiación europea, es decir, desarrollar su vida en medio de las instituciones de dominio colonial,

65 Abercrombie, “Articulación doble,” 203-204.

Artificios. Revista colombiana de estudiantes de historia. No. 5. Agosto de 2016. ISSN. 2422-118X 
es a través de ellos que se puede percibir como se pone en marcha el engranaje del sincretismo cultural. A la luz de los elementos hispánicos se reactualiza el pasado indio, en tanto éstos son actores conscientes del devenir histórico y no meros instrumentos de poder de las élites, muchas veces desarrollándose este proceso a nivel doméstico.

En el caso de Corpus Christi vemos como una elite local andina se legitima en una celebración netamente cristiana, ya no a través de las armas, sino de la hibridación cultural adoptando las normas cortesanas y los cánones de legitimidad españoles. Como lo entiende Dean ${ }^{66}$ el festejo de Corpus es por un lado la victoria de los españoles sobre los incas, pero por otro la presencia de los soberanos incaicos hace partícipe del triunfo mismo a los indios. A su vez estas representaciones están fuertemente influidas por las nociones europeas de nobleza, dándose un proceso de transculturación en dos sentidos, de los españoles a los nativos y viceversa. Lo que esta autora olvida es que las realidades de las élites nativas y sus problemáticas no son ni mucho menos las de los indígenas en sentido amplio, por lo que considerar a las representaciones nobiliarias como extensibles a la sociedad indígena en general, debe ser relativizado.

Lo anterior nos lleva a considerar que las sociedades indígenas son tanto el producto de una historia específica, como resultado de su capacidad de desarrollar estrategias de resistencia y adaptación. Estas últimas se inscriben en la continuidad de prácticas y representaciones anteriores a la conquista, aunque desembocaron también a través de procesos de aculturación de distinta índole, en la aparición de nuevas subjetividades e identidades en la sociedad colonial y poscolonial. ${ }^{67}$ En lugar de afrontar perturbaciones ocasionales a partir de un orden siempre dispuesto a rehacerse, la mayoría de los sistemas manifiesta comportamientos que fluctúan entre distintos estados de equilibrio, sin que exista forzosamente un

66 Dean, Inka bodies, 97-99.

67 Guillaume, Boccara, “¿Qué es lo 'etno' en etnohistoria? La vocación crítica de los estudios etnohistóricos y los nuevos objetos de lucha”, Memoria americana 35-181 (2012): 39.

Artificios. Revista colombiana de estudiantes de historia. No. 5. Agosto de 2016. ISSN. 2422-118X 
mecanismo de regreso a una "normalidad". Por el contrario, a largo plazo la reproducción de estados aparentemente similares termina por crear situaciones nuevas. ${ }^{68}$ Si bien debemos considerar que los españoles con su cultura y sus lógicas se impusieron mediante la coerción y la violencia sobre el Mundo Andino, intentando negar y destruir el pasado prehispánico, la importancia y la presencia de la tradición andina impidió que la imposición de una nueva cultura borrara las huellas prehispánicas. Muchas tradiciones europeas debieron ser andinizadas para lograr ser aceptadas por los subalternos andinos, dentro de lo cual el festejo de Corpus Christi no deja de ser una expresión más de un proceso de mestizaje socio cultural, que lógicamente no dejó de reflejar estos cambios tanto para los andinos como para los europeos.

El caso de Cuzco se presenta en este nivel paradigmático, ya que permite evidenciar de maneras más claras que en otras zonas de los Andes la relación establecida entre las distintas élites dentro del sistema colonial. En la antigua capital incaica, los descendientes de los últimos soberanos gozaban de un prestigio inusitado tanto en su figura personal como en el respeto y estatus que tenían sus tradiciones y costumbres ancestrales. Tal como señala Serulnikov ${ }^{69}$ "desde mediados de siglo (XVII), un antiguo culto a la antigüedad incaica floreció en el Cuzco, propagado tanto por los criollos, que adoptaron la vestimenta y los adornos incas, como por los caciques que exhibían orgullosamente el antiguo símbolo del Dios Sol y de los incas en las ceremonias públicas". De esta manera, el sistema colonial permitía la reproducción de la cultura prehispánica a través de la educación y el ritual público, a través de las representaciones dramáticas y celebraciones de la élite indígena y blanca. Las contradicciones inherentes al sistema de dominación colonial, constituido por una amplia red de tramas porosas y permeables en donde los distintos protagoni-

68 Gruzinski, El pensamiento mestizo, 124-125.

69 Sergio Serulnikov, Conflictos sociales e insurrecciones en el mundo colonial andino. El norte de Potosi en el siglo XVIII (Buenos Aires:Fondo de cultura económica, 2006): 422.

Artificios. Revista colombiana de estudiantes de historia. No. 5. Agosto de 2016. ISSN. 2422-118X 
stas podían intervenir y decantar sus intereses a través del juego de relaciones entre las élites locales y la Metrópoli se evidencian desde una etapa muy temprana. Los distintos elementos andinos que vemos mutados dentro de la fiesta del Corpus nos pueden indicar como los procesos de mestizaje cultural se gestan a través de una estrecha relación entre los distintos grupos sociales, en donde aquellos que aparentemente tienen un rol subalterno, en realidad si son capaces de reconstruir su propia historia y reproducirla en canales viables, a través de los marcos culturales de la tradición occidental.

En este entramado, la élite cuzqueña lentamente va adquiriendo un lugar predominante en el escenario colonial, en donde la comunidad política aparece como una entidad plural conformada por diversos grupos sociales y no sólo como un monopolio hispano $^{70}$. Excedería el alcance de este trabajo dilucidar las relaciones que se establecen entre las élites indígenas del siglo XVI y sus homónimas del siglo XVIII, sin embargo, podemos pensar que ya desde un período muy temprano estas se hallaban totalmente asimiladas al orden colonial, situación que para la época de las sublevaciones andinas ocasionaría una seria impugnación a los cimientos de la dominación española, destruyendo el sustrato ideológico de la misma: el carácter subalterno de las poblaciones indígenas frente a los europeos.

$70 \quad$ Serulnikov, Conflictos sociales e insurrecciones

Artificios. Revista colombiana de estudiantes de historia. No. 5. Agosto de 2016. ISSN. 2422-118X 


\section{Bibliografía}

Abercrombie, Thomas. "Articulación doble y etnogénesis" en Reproducción y transformación de las sociedades andinas. Siglos XVI-XX. Quito: Abya Yala, 1991.

, Caminos de la memoria y del poder. Etnografia e historia en una comunidad andina. México D.F.: Sierpe publicaciones, 2006.

,"To be Indian, to be Bolivian: ethnic and national discourses of identity". En: Nation-states and indians in Latin America, editado por Greg Urban y Joel Sherzer, 95-131. Austin: Univeristy of Texas Press, 1991.

Baker, Geoffrey. "Music at Corpus Christi in colonial Cuzco", Early music 32, 3 (2005): 355 - 367.

Bernales Ballesteros, Jorge "El Corpus Christi: Fiesta barroca en Cuzco", Actas de las I jornadas de Andalucía y América, II (1981):275-290.

Boccara, Guillaume. “¿Qué es lo 'etno’ en etnohistoria? La vocación crítica de los estudios etnohistóricos y los nuevos objetos de lucha", Memoria americana 20 (2012): 35-181.

Bovisio, María Alba. "Los muertos, otra corporalidad: acerca del imaginario sobre la muerte através de las fuentes de extirpación de idolatrías (siglos XVI y XVII)". Actas del VI Congreso Internacional de Etnohistoria, FFyL, UBA, Buenos Aires, (2005): 1-14.

Bridikhina, Eugenia. "La ciudad y la corte como espacios de poder en Hispanoamérica. La Plata colonial”, Revista de Indias 67- 240, (2007): 553 - 572.

, "La propaganda política y creación del nuevo lenguaje festivo en los primeros años de la república de Bolivia: rupturas y continuidades", Espacio, tiempo y forma, revista de la facultad de Geografía e Historia Serie V, 22, (2010): 235 - 255.

, Theatrum Mundi, entramados del poder en Charcas colonial. Lima: Instituto Francés de Estudios Andinos, 2007. 
Cañeque, Alejandro. "De sillas y almohadones o de la naturaleza ritual del poder en la Nueva España de los siglos XVI y XVII”, Revista de Indias 64-232, (2004): $609-634$.

Carmagnani, Marcello. El regreso de los dioses. El proceso de reconstitución de la identidad étnica en Oaxaca, siglos XVII-XVIII. México DF: Fondo de cultura económica, (1989)

Dean, Carolyn. Inka bodies and the body of Christ: Corpus Christi in colonial Cuzco, Peru. Carolina del Norte: Duke University Press, 1999.

Decoster, Jean-Jacques. "Identidad étnica y manipulación cultural: La indumentaria inca en la época colonial”, Estudios atacameños 29, (2005): 163 - 170.

Etchelecu, Leontina. "Diversas formas que adopta la religión andina. Yuxtaposiciones peligrosas", Hispania sacra 59-119, (2007): 293 - 301.

Focault, Michael, "Las redes de poder", Farenheit450 1, (1986).

Gareis, Iris. "Los rituales del Estado colonial y las élites andinas", Bulletin de l'Institut français d'études andines 37-1, (2008): 97 - 109.

Gruzinski, Serge. El pensamiento mestizo. Cultura amerindia y civilización del renacimiento. Barcelona: Paidós, 2007.

Millones, Luis. "Las ropas del Inca: Desfiles y disfraces indígenas coloniales", Revista de crítica literaria latinoamericana 21-41, (1995): 51 - 66.

Palomeque, Silvia, "El sistema de dominación colonial en Andes de páramo", (inédito). Material de Lectura de la Cátedra Historia de América 1 - UNC, Córdoba, (1996):1 - 18.

Pratt, Mary Louise, “Arts of the contact zone”, Profession, (1991): 33-40.

, Imperial eyes: Travel writing and transculturation. Londres: Routledge, 2008. 
Queija, Berta. "Las danzas de los indios: un camino para la evangelización del virreinato del Perú", Revista de Indias 44-174, (1984): 445- 463.

Salomon, Frank. "Superman es más súper cuando se quita la malla", Chungara, Revista de Antropología Chilena 45-4, (2013): 515 - 522.

Serulnikov, Sergio. Conflictos sociales e insurrección en el mundo colonial andino. El norte de Potosí en el siglo XVIII. Buenos Aires: Fondo de cultura económica, 2006.

Taylor, Gerald. Sermones y ejemplos. Antología bilingüe castellano-quechua Siglo XVII, Vol 17. Lima: IEA -Lluvia Editores, 2002.

Thompson, Edward Palmer. Costumbres en común: estudios en la cultura popular tradicional. Barcelona: Crítica, 1991.

Valenzuela Márquez, Jaime. "... que las ymagenes son los ydolos de los christianos" Imágenes y reliquias en la cristianización del Perú (1569-1649), Jahrbuch für Geschichte Lateinamerikas 43, (2006): 41 - 65.

Villegas, Samuel. "El movimiento del Taqui Onkoy (Huamanga, siglo XVI)", Investigaciones Sociales, 15(26), (2011): 115-130.

\section{Fuentes}

AA.VV. Historiadores de Indias (Madrid: Oceáno, 1999): 73-157.

Colección de óleos de Corpus Christi (ca. 1674-1680), Obras: "Santiago", "San Sebastián", "Virgen de Belén", "San Cristobal", "Santa Rosa y La Linda". En Museo de Arte Religioso del Palacio Arzobispal de Cusco.

De Albornoz, Cristobal. [ca. 1584], "Instrucción para descubrir todas las guacas del Pirú y sus camayos y haziendas”: (Arriaga 1920:42 [1621: Capítulo IV]).

De Ávila, Francisco. [1646] "La Epifanía del señor y pascua de los Reyes”. En Gerald Taylor, Sermones y ejemplos. Antología bilingüe castellano-quechua Siglo XVII, Vol 17, (IFEA -Lluvia Editores, Lima, 2002). 
De Xerez, Francisco y De Estete, Miguel. Verdadera relación de la conquista del Perú Vol. 1. (Tip. de JC García, 1891).

De Murúa, Fray Martin. "Historia general del Perú" en Manuel Ballesteros Gaibrois, ed., Colección Crónicas de América. (Madrid: Historia 16, 1987) 453.

De Ondegardo, Juan Polo. "Relación de los fundamentos acerca del notable daño que resulta de no guardar a los indios sus fueros" en Colección de Libros y Documentos referentes a la Historia del Perú, 1, ([1571] 1916)

Guamán Poma de Ayala, Felipe. Nueva coronica y buen gobierno [1584-1615]. Franklin Pease García (ed).

Hanke, Lewis (ed.), Los virreyes españoles en América durante el gobierno de la casa de Austria. (México, Biblioteca de Autores Españoles, vol. CCLXXV, Madrid): 267-270.

Urteaga, Horacio y Romero, Carlos Alberto (ed.), Fundación española del Cuzco y Ordenanzas para su gobierno. (Lima: Talleres gráficos Sanmartí y cía, 1926), 87-91. 